Article

\title{
Doing Good or Avoiding Evil? An Explorative Study of Depositors' Reasons for Choosing Social Banks in the Pre and Post Crisis Eras
}

\author{
Nikolas Höhnke \\ Department of Business Administration, University of Rostock, 18057 Rostock, Germany; \\ nikolas.hoehnke@uni-rostock.de
}

Received: 21 October 2020; Accepted: 1 December 2020; Published: 3 December 2020

\begin{abstract}
The global financial crisis is expected to be of great relevance for social banks' growth of deposits. However, it is still unclear why depositors choose social banks in general, and how the global financial crisis has affected depositors' choice of social banks. The present paper thus explores a comprehensive set of reasons for choosing social banks, the individual relevance of reasons, as well as differences before and after the global financial crisis. Data was collected through a survey of five social banks, interviews with nine industry experts, and an online survey with 108 social and 413 conventional depositors. Using content analysis, a multi-level system of reasons for choosing social banks was identified, which refers to the social banks' "good" and conventional banks' "evil" characteristics. Based on a frequency analysis of codings per category, reasons with potential superior relevance for depositors' decision-making were explored. A comparison with reasons for choosing conventional banks imply that depositors' reasons for choosing social banks differ from those for choosing conventional banks in general. The results also indicate that the global financial crisis might have helped social banks' growth by attracting new customer target groups, who chose social banks because of conventional banks' "evil" characteristics.
\end{abstract}

Keywords: content analysis; ethical banking; global financial crisis; hierarchical cluster analysis; inductive category development; in-depth interviews; social banking; socially responsible investment

\section{Introduction}

Financing sustainable projects through customer deposits has played a minor role in the Socially Responsible Investment (SRI) universe and is primarily offered by a few specialised banks [1], which are called social, sustainable, or ethical banks. However, the deposits of these social banks have grown massively in recent years [2-5]. The global financial crisis is considered to be significant to the rise of social banks [6-8]. However, even one decade later, the relevant literature has not offered a sound explanation for how the global financial crisis has affected depositors' choice of social banks. In the light of the current COVID-19 pandemic and its (expected) impact on the global economy, a sound explanation of the impact of the global financial crisis on the growth of social banks could give valuable insights into current and future crises. One reason for this lack of evidence might be the remaining uncertainty about depositors' reasons for choosing social banks in general. Previous research has assumed that private customers hold deposits with social banks to give their money real meaning, to receive an extra stream of utility, and to reinforce their pro-social identity by financing social business projects [7-9]. However, Höhnke and Homölle [10] show that social banks' placement of assets alone cannot explain depositors' choice of social banks and argue that other reasons for choosing social banks must exist. The relevant literature has offered neither a comprehensive overview of depositor reasons for choosing social banks nor an analysis of the individual relevance of reasons for depositor 
decision-making. As a consequence, social depositor decision-making remains a black box. The lack of a sound explanation of past growth prevents the sound prediction of future growth, bringing about massive uncertainty and poorer decisions for all manner of decision makers.

Social banks will not be able to set their expansion strategy in motion efficiently (e.g., proactively hire new employees or open new branch offices). In the light of the current global COVID-19 pandemic, missing insights on the impact of the global financial crisis on depositors' choice of social banks prevent a sound assessment of whether the pandemic could lead to a second boom in social bank deposits or e.g., to a bank-run threat.

In recent years, some conventional banks have started to adopt social banking principles. In this context, it is expected that the future growth of the social banking movement might be carried by conventional banks that have turned into social banks [10]. However, it seems reasonable to expect that a significant transformation process of the banking industry requires sufficient evidence of customer needs and decision-making.

It remains unclear whether social banks' growth has been a short-term sugar hill or the beginning of a sustainable regime shift in the commercial banking industry, comparable to those of the organic grocery industry over the past two decades. Consequently, standard-setters and policy makers will not be able to monitor or support this potential development into a more sustainable financial industry by creating appropriate (legal) frameworks, such as transparency requirements.

The lack of evidence regarding depositors' reasons for choosing social banks and the impact of the global financial crisis on depositors' choices could thus lead to missed opportunities, undetected threats, inefficient management, and a lack of political support. The purpose of this paper is thus to identify (1) a comprehensive set of depositor reasons for choosing social banks, (2) the individual relevance of these reasons for the choice of social banks, and (3) the development of social depositor reasons over time. This will be used to shed some light on the impact of the global financial crisis on social banks' growth.

Against this background, the present study comprises a mixed-method explorative research approach. A comprehensive set of depositors' reasons for choosing social banks was explored by creating a structured multi-level system of categories (reasons), using content analysis based on data collected via surveys with five social banks, as well as nine interviews with industry and academic experts. The individual relevance of these reasons was investigated with a frequency analysis based on data from an online survey of 108 social and 413 conventional depositors. To explore the variety of depositor reasons for choosing social banks, the development of customer groups in social banks was observed. Depositors were classified using a hierarchical cluster analysis based on the self-stated and classified reasons for choosing social banks from the 108 social depositors.

Based on this consecutive empirical research design, this paper seeks to make the following contributions to the existing literature: (1) extend the spectrum of depositor reasons for choosing social banks, (2) increase the understanding of known reasons, (3) identify the main reasons of social depositors, (4) differentiate these reasons from those for choosing conventional banks, and (5) create an initial empirical-based explanation for the impact of the global financial crisis on social banks' growth of deposits. These contributions will help to unlock the black box of social depositor decision-making, and in turn explain the growth of social banks in the aftermath of the global financial crisis.

The remainder of the paper is structured as follows: Section 2 gives a brief overview of the basic concept of social banking, social banks' growth, and depositor reasons for choosing social banks. Sections 3-5 deal with a comprehensive set of depositor reasons for choosing social banks, the individual relevance of these reasons for the choice of social banks, and the development of social bank customer groups over time. Section 6 presents potential limitations, implications, and avenues for further research. The paper ends with a summary and conclusion. 


\section{Literature Review}

While most of the scientific literature on SRI has focused on institutional investors in capital markets (e.g., [11-13] for a literature overview), only a few studies have contributed to private (retail) investors of SRI funds (e.g., [14-17]), and even fewer to the field of SRI on credit markets, such as social banking and social depositors.

Social banks, also known as ethical, green, sustainable, or alternative banks [18-20], are financial intermediaries that run a commercial banking business with the objective of creating a social or environmental impact while making sufficient profits for banks' going concern [5]. Social or environmental value is not created by social banks themselves, but rather by the entities that are funded by them $[8,20,21]$. For this purpose, social banks primarily collect savings to distribute loans $[8,19]$, resulting in high deposits-to-assets and loans-to-assets ratios [7]. As most conventional banks do not offer sustainable saving products [1], social banks dominate the sustainable credit market, which shows great potential for further growth by attracting further depositors [22].

Social banks differ from conventional banks particularly in their asset placement, level of transparency (concerning the placement of assets), and the possibility of customer participation $[8,23]$. The placement of assets of social banks is characterized by their non-application of speculative activities and the self-limitation of their use of funds $[8,19,23]$. Some social banks merely invest in projects that create social or environmental value (impact investing strategy). Other social banks do not invest in projects that create a social or environmental harm, but in all other projects providing a positive or neutral impact (exclusion strategy) [10]. Publicly disclosed investment criteria define which projects have a negative impact, such as nuclear energy, genetic manipulation, animal testing, pornography, drugs, and armaments [23,24], or a positive impact, such as organic farming, renewable energy, sociaL businesses, and fair trade products $[8,23,25,26]$.

Social banks show transparency regarding the social and environmental impact of their investments to a greater degree than conventional banks [23]. Most social banks disclose at least aggregated information about their fund usage. Some social banks even disclose all of their distributed loans and securities under management in detail $[8,23]$. Stakeholders are thus able to monitor the suitability of their investment preferences with their social bank's placement of assets. Social banks thus remove the barrier between depositors and borrowers, whereas both groups are kept separated and anonymous in conventional banking [8].

Some social banks go one step further, extending customer participation by allowing depositors to choose the fields their funds are used for. Furthermore, depositors can obtain a reduction in interest rates if their funds are used for projects of their choice [8,27].

The relevant literature on social banking provides two approaches to explain the choice of social banks, primarily referring to the differences between social and conventional banks. First, with reference to Akerlof and Kranton's [28] theory of how identity (a person's sense of self) affects economic outcomes (such as saving behaviour), Cornée and Szafarz [7] argue that private customers hold deposits with social banks to receive an extra stream of utility and reinforce their social identity. In this vein, social depositors show a greater preference for sustainable buying behaviour, social return, transparency, and participation, and place less importance on financial return than conventional depositors [22]. Bayer et al. [29] show that a reduced economic benefit generally discourages conventional depositors from switching to a social bank, indicating that social depositors might be a special customer group.

Second, Höhnke and Homölle [10] argue that the choice of social banks could also be a rejection of conventional banks, reflecting that "bad" events, personal action, or traits have a stronger impact on behaviour than "good" ones $[30,31]$. Social depositor preference for transparency and participation might come from negative experiences with conventional banks.

As customer groups may consist of a mixture of sub-groups with different motives, both (or more) explanations for depositors' choice of social banks could be equally valid. Comparing these approaches to the set of reasons for choosing banks in general reveal that both explanations for choosing social 
banks might be unique. Bayer et al. [29] collected a set of 15 bank selection criteria for depositors' choice of (conventional) banks from the relevant literature and formed four clusters based on content-related commonalities (see Table 1). It remains unclear whether some of the bank selection criteria could also be of relevance for depositors' choice of social banks. The relevant literature does not offer an overview of reasons for choosing social banks that enables a differentiated analysis of customer behaviour and customer groups.

Table 1. Clustered Criteria for Choosing Conventional Banks.

\begin{tabular}{ccl}
\hline No. & Cluster & Bank Selection Criteria \\
\hline 1 & & Location of ATMs and bank branches \\
2 & & Branch opening hours \\
3 & Convenience & Parking facilities \\
4 & & Display of counters \\
5 & & Disposal of electronic services \\
\hline 6 & Economic benefit & Fees \\
7 & & Charges \\
8 & \multirow{2}{*}{ Reputation } & Rates of interest \\
\hline 9 & & Recommendations \\
10 & & public image \\
\hline 11 & & Speed of service \\
12 & & Responsiveness \\
13 & Service quality & Reliability \\
14 & & Offering of incentives \\
15 & & Competence of employees \\
\hline
\end{tabular}

Source: Own table; based on the literature review and clustering of Bayer et al. [29].

Over the past two decades, social banks' deposits have shown annual growth rates of up to $30 \%$ [2-4]. Deposits in German social banks grew from $€ 1.474$ billion to $€ 7.273$ billion between 2007 and 2017 , reflecting a relative growth of $493 \%$ over one decade [10]. The global financial crisis of 2007/2008 is expected to be of great importance for social banks' growth [6-8]. However, the literature has not offered an appropriate explanation for how the financial crisis has helped social banks' growth. It thus remains unclear whether social banks' growth was a short-term sugar hill or a sustainable regime shift in the commercial banking industry.

\section{Depositor Reasons for Holding Deposits with Social Banks}

Since a comprehensive overview of depositor reasons for choosing social banks is lacking in the relevant literature, a multi-level system of reasons (categories) will be explored in this section. This category system increases the basic understanding of depositors' decision-making and will help subsequent research by providing an initial, empirically derived set of depositor reasons.

\subsection{Data Collection}

The most intuitive data sources for exploring a multi-level system of depositor reasons for choosing social banks are the depositors themselves. However, as both subsequent analyses (Sections 4 and 5) are based on depositor data only, the multi-level system of reasons is built based on data from market experts in the first place and reviewed based on data from social depositors in Section 4.3.1. This dual approach enables the most resilient fundament for this consecutive study setting. Interviews with industry experts and academics, as well as a survey of social bank board members, are used to build the system of categories. Based on their experience, market knowledge and overviews, experts were expected to describe a wide range of reasons (including rare ones), as well as the internal structure of these reasons, by grouping reasons that frequently come along with one another, for example. 
Expert statements on the motives of customers are expected to be largely free of social desirability and to provide a high degree of discrimination among categories.

In-depth interviews were used to collect data from industry experts, researchers, and customer account managers of social banks (see [32,33] for comparable approaches in the SRI and banking context). Nine experts were interviewed between October 2017 and January 2018. At the beginning of the interviews, interviewees were asked to describe the individual experience that qualifies them to report upon depositor reasons for choosing social banks. The sample of interviewees is described in Table 2, including the participant's relevant work experience, to soundly answer the following five questions:

1. Why do depositors choose a social bank (or your bank)?

2. Are these reasons of equal relevance for depositors' choice, or are some more important?

3. Do these reasons differ between customer groups?

4. Which of these reasons is currently the most important one?

5. Have these reasons changed over time?

Table 2. Relevant work Experience of Interviewees.

\begin{tabular}{ccl}
\hline No. & \multicolumn{1}{c}{ Job Title } & \multicolumn{1}{c}{ Relevant Work Experience } \\
\hline 1 & Customer account manager & Four years in customer account management for a German social bank \\
\hline 2 & Head of customer account management & Five years in customer account management for a German social bank \\
\hline 3 & Senior customer account manager & Nine years in customer account management for a German social bank \\
\hline 4 & Investment advisor & $\begin{array}{l}\text { One year in investment advisory (for retail customers) for a German } \\
\text { social bank }\end{array}$ \\
\hline 5 & Managing director/Board member & Managing director and board member of a topic related association \\
\hline 6 & Board member/Researcher & $\begin{array}{l}\text { Board member of a topic related association; } \\
\text { Research on social banking (several publications) }\end{array}$ \\
\hline 7 & Researcher/Manager & $\begin{array}{l}\text { Co-founder and Manager of a topic related association; } \\
\text { Ph.D. thesis on social banking }\end{array}$ \\
\hline 8 & Researcher/Board member & $\begin{array}{l}\text { Research on social banking (several publications); } \\
\text { Board member of a European social bank; } \\
\text { Advisory board member of a topic related association }\end{array}$ \\
\hline 9 & Researcher & $\begin{array}{l}\text { Ph.D. thesis on social banking; } \\
\text { Several studies on social banking in cooperation with a topic } \\
\text { related association }\end{array}$ \\
\hline
\end{tabular}

To ensure that the construction of the interview guideline did not limit the answers, interviewees were able to add any relevant information at the end of the interview.

Board members of German-speaking social banks also received a survey that (i.a.) included two questions concerning why depositors chose social banks: "Why do depositors choose your bank?" and "How have these reasons changed over time?" The survey was sent out to the executive offices of seven German-speaking social banks in November 2017. These social banks were selected based on the scientific literature $[8,22,23]$ and the membership lists of relevant international associations, such as the Global Alliance for Banking on Values (GABV) [34], the Fédération Européenne des Banques Ethiques et Alternatives (FEBEA) [35], and the Institute for Social Banking (ISB) [36]. In this paper, social banks do not comprise confessional or church banks (just as in $[23,24]$ ), since the enormous growth reported (e.g., by [2-4]) refers to non-confessional social banks. Five social banks took part in the survey, representing approximately $92 \%$ of all the deposits of German-speaking social banks.

\subsection{Methodology}

Based on data from the interviews and the survey, content analysis was used to build a multi-level system of categories regarding depositor reasons for choosing social banks. Content analysis is a research method that objectively and systematically identifies specific characteristics in textual data, 
in order to identify, for example, the intentions or attitudes of individuals [37]. Content analysis is a common research method in the fields of CSR in the banking industry and in sustainable investing for analysing verbal or textual data from various sources, such as bank websites, annual reports, interviews with experts, or surveys [1,38-41].

Because of the lack of evidence for the variety of depositor reasons for choosing social banks and the resulting explorative setting of this study, inductive category development (see [42] for an introduction) was used to build the categories. The entire interview material, as well as the social banks' answers to the surveys, were cut down to statements that may describe depositors' reasons for choosing social banks, using a small unit of analysis and creating a first list of relevant statements. Manual coding was preferred to automatic coding due to the explorative setting of this study and potential divergence of vocabulary between different expert groups (see [41] for a comparable argumentation). Even though manual coding is expected to decrease reliability (in terms of consistency and reproducibility) and transparency in the coding process [37,41], manual coding is supposed to provide more complexity and separation-precision among categories, since computerised word count strategies are generally unable to capture context and linguistic devices sufficiently [43]. Furthermore, automated coding (computerised word count strategies) requires a sound understanding of the research subject (e.g., based on theory or sufficient empirical findings to define the set of search terms). As this explorative study initially aims to identify the set of reasons for choosing social banks, the basic understanding of the research subject is too limited to use automated coding.

Following Mayring's [42] process proposal of inductive category development, the categories were first created by the author based on around $35 \%$ of the data set. For this purpose, data from five randomly selected interviews and surveys was processed. The subsample included two social bank employees, one employee of a related association, one researcher, and one survey, thus providing a reasonable diversity of data sources. Each category had a simple but accurate name, description, and representative example. Afterwards, the entire list of statements was processed to develop the full (unstructured) set of depositor reasons for choosing social banks. In accordance with Mayring [42], two independent coders, without specific knowledge of the topic "social banking", were trained to check the author's coding. Both coders assigned the statements to the set of categories built, using category names, descriptions, and examples. Based on these coding results, the inter-coder reliability was calculated.

To structure the set of categories built, the interview material was examined again for statements that could describe a super-ordinated structure (main categories). Additionally, mid-level categories were built based on topic-specific commonalities of categories, further increasing the clarity of the system. To check the reliability of the structuring process, two independent coders assigned all the categories to the structured system of main and mid-level categories.

The entire study, including the data collection, processing, and analysis, was executed in German, since all the coders, interviewees and social banks come from German-speaking countries. Results cannot therefore be driven or influenced by translation-based issues.

\subsection{Results}

Based on material from nine interviews and five banking surveys, 81 statements concerning depositors' reasons for choosing social banks were identified. These statements were assigned to 19 categories, with a minimum of one and a maximum of 13 codings. Some statements were assigned to more than one category. For instance, the statement "... I give my money to a bank that supports local things or the real economy ... " were assigned to the categories "Preference for investments in the real economy" and "Preference for investments in local or regional projects" (see Table 3). It is assumed that the term "investments in the real economy" means investments (loans and securities) in companies from the primary, secondary, and tertiary sectors of the economy, but not investments in synthetic financial assets, such as financial derivatives. 
Table 3. Depositors' Reasons for Choosing Social Banks.

\begin{tabular}{|c|c|c|}
\hline Category Name & $\begin{array}{c}\text { Category Description } \\
\text { Category Includes Statements that Address ... }\end{array}$ & No. of Codings \\
\hline $\begin{array}{l}\text { Rejection, disappointment and mistrust towards conventional } \\
\text { banks and the financial system }\end{array}$ & $\begin{array}{l}\text {... a general rejection of conventional banks, as well as incidences that lead to rejection, } \\
\text { disappointment or mistrust of conventional banks or even the entire financial system. }\end{array}$ & 13 \\
\hline Preference for social and environmental investments & $\begin{array}{l}\text {... depositors' preference for concrete social or environmentally friendly fields of investments or } \\
\text { a general preference for using money in a positive manner. }\end{array}$ & 12 \\
\hline Shared values & $\begin{array}{l}\text {... a base of shared values between depositors and social banks, as well as depositors' } \\
\text { preference for the social banks' principles, characteristics and actions. }\end{array}$ & 11 \\
\hline Rejection of specific fields of investments & $\begin{array}{l}\text {... depositors' rejection of specific fields of investments, as well as a general rejection of social or } \\
\text { environmental harmful investments. }\end{array}$ & 7 \\
\hline Consulting and service & $\begin{array}{l}\text {... the (good) quality of social banks' consulting and services, as well as the satisfaction of } \\
\text { customer needs and wishes. }\end{array}$ & 6 \\
\hline Transparency of investments & $\begin{array}{l}\text {... depositors' preference for transparency in investments, meaning in particular the desire to } \\
\text { know how customer money is used. }\end{array}$ & 5 \\
\hline Perceived relevance of banks for the society and environment & $\begin{array}{l}\ldots \text { the general understanding by depositors that banks have an impact on the environment and } \\
\text { society, as creditors and investors in the economy. }\end{array}$ & 4 \\
\hline Comprehensive product range & ... the range of social banks' products and services, but not the service quality itself. & 3 \\
\hline Trust in social banks & ... depositors' trust in social banks, but not the mistrust in conventional banks. & 3 \\
\hline Engagement outside the banking business & $\begin{array}{l}\text {... depositors' preference for social banks which engage outside their original banking business, } \\
\text { such as political debates, support of social projects or sustainable education. }\end{array}$ & 3 \\
\hline Conditions (interest and costs) & ... attractive cost conditions, as well as an appealing interest rate. & 3 \\
\hline Recommendation & $\begin{array}{l}\text {... recommendation of third persons about specific characteristics of social banks or social banks } \\
\text { in general. }\end{array}$ & 3 \\
\hline Rejection of speculative trading & $\begin{array}{l}\text {... a general rejection of banks' speculative activities, as well as of specific speculation activities, } \\
\text { such as food speculation. }\end{array}$ & 2 \\
\hline Preference for investments in the real economy & $\begin{array}{l}\ldots \text { depositors' preference for the use of their deposits for investments in real companies and not } \\
\text { for investments in financial instruments. }\end{array}$ & 2 \\
\hline Rejection of profit maximisation & $\begin{array}{l}\text {... depositors' rejection of businesses that solely serve a bank's profit maximisation, as well as } \\
\text { profit maximisation as a bank's main aim. }\end{array}$ & 1 \\
\hline Option to choose preferred fields of investments & ... the possibility of depositors to directly choose in which fields their deposits should be used. & 1 \\
\hline Preference for local or regional investments & ... the preference for using deposits for investments in local or regional companies. & 1 \\
\hline Friends or family members are depositors of social banks & ... friends or family members that are depositors of social banks, but not their recommendation. & 1 \\
\hline
\end{tabular}


Two statements were assigned to the category "Knowledge of the existence of social banks". Hereinafter, it was expected that knowledge of the existence of social banks was a mandatory requirement for the choice of a social bank. This category is thus excluded from the list of reasons. However, earlier findings have highlighted the relevance of informational deficits concerning the existence or meaning of social banking as core barriers for customers to switch to social banks [3]. Therefore, the exclusion of this category should not reduce the expected importance of an increase in public knowledge of social banks for their growth in deposits. It is instead expected that "Knowledge of the existence of social banks" is one core driver for an increasing number of decision-making depositor processes. However, this study aims to describe the factors of the decision-making itself, rather than the quantity of decisions made. Table 3 thus shows the remaining 18 categories, including a description of the category and the number of codings per category.

Based on the assignment of statements by two independent coders, an intercoder reliability of $80.77 \%$ was revealed. Comparing this result to Landis and Koch's [44] benchmarks for Cohens Kappa, the intercoder reliability is "substantial", and close to "almost perfect". Moreover, both coders assigned at least one statement per category consistently with the author, indicating a reliable identification of reasons based on the present data set.

The reasons identified include several categories that have already been addressed by scholars, such as the relevance of social banks' investment selection or transparency [22,23]. However, the findings revealed a higher degree of precision among these well-known reasons. For instance, at least seven categories directly refer to the relevance of the investment selection. The set of categories also includes reasons that have not been addressed in the literature on social banking so far, such as "Engagement outside the banking business" or "Conditions (interest and costs)".

To increase the degree of exploration regarding depositors' reasons for holding deposits with social banks, the unstructured set of reasons is transferred into a structured multi-level category system, providing insights into the content-related relations among categories. Three interviewees gave insights into the internal structure of depositor reasons for choosing social banks. The following statements come from a private customer account manager of a German social bank, a board member of a topic related association (with scientific background in the field of social banking), and a researcher in the field of social banking.

Interviewee 3:

"[ ... ] does the customer wants to get away (from something) or does the customer wants to get towards (something). In recent years, I have seen that customers want to get away from something; that they are unsatisfied with their (current) situation. [ ... ] I started to work here at the beginning of the bankruptcy of Lehmann Brothers (2008), and from that point on our very strong growth began. [... ] (In the past,) I think that there were more customers who thought more about the 'towards'. [... ] We have talked a lot here (in the bank) in recent years about how this has changed, and I conclude that we have just spread to a wider spectrum (of customers). [ ... ] we started to address other people who had not dealt with a sustainable bank eight or nine years ago."

Interviewee 6:

"[ ... ] there are people who try to do something positive with their money, to create something meaningful, and there are (other) people who at least do not try to create damage or hand over their money to the bad banks. However, there is certainly a group of people who are interested in both. [ ... ] You have to distinguish between old and new customers. For new customers, it is more an avoidance of conventional banks (which are seen as evil) towards positively-perceived banks. [ ... ] Currently, it is more a strategy of avoidance as a consequence of the financial crisis. [ ... ] At the beginning of the social banking movement, the need to do something positive in a specific sector was maybe stronger."

Interviewee 9:

"I would say that there are two main motives. Some (customers) are social-environmental oriented [ ... ]. And for many others, it was a protest against big banks and how they deal with money. [ .. ] Especially 
for people who switched after 2008, many thought about that (to switch to a social bank) because of the financial crisis."

Expert statements indicate that social bank depositors belong to one of two groups: people who try to create something positive (for society and the environment) by choosing a social bank ("towards"), and people who try to avoid harm by leaving a conventional bank for a social bank ("get away"). Based on this logic, all 18 reasons identified in the previous sub-section are assigned to reasons that primarily describe the avoidance of conventional banks ("get away") or reasons that primarily indicate depositors' preference for social banks' characteristics ("towards"). These two groups of reasons define the primary structuring logic and thus the root categories of the category system. Fourteen reasons were assigned to the root category "towards". These 14 categories were additionally assigned to four topic specific mid-level categories, in order to increase clarity and ease the accessibility of the category system. The remaining four reasons were assigned to the root category "get away". Because of the low number of "get away" reasons, no mid-level categories were built (see Table 4).

Table 4. System of Categories.

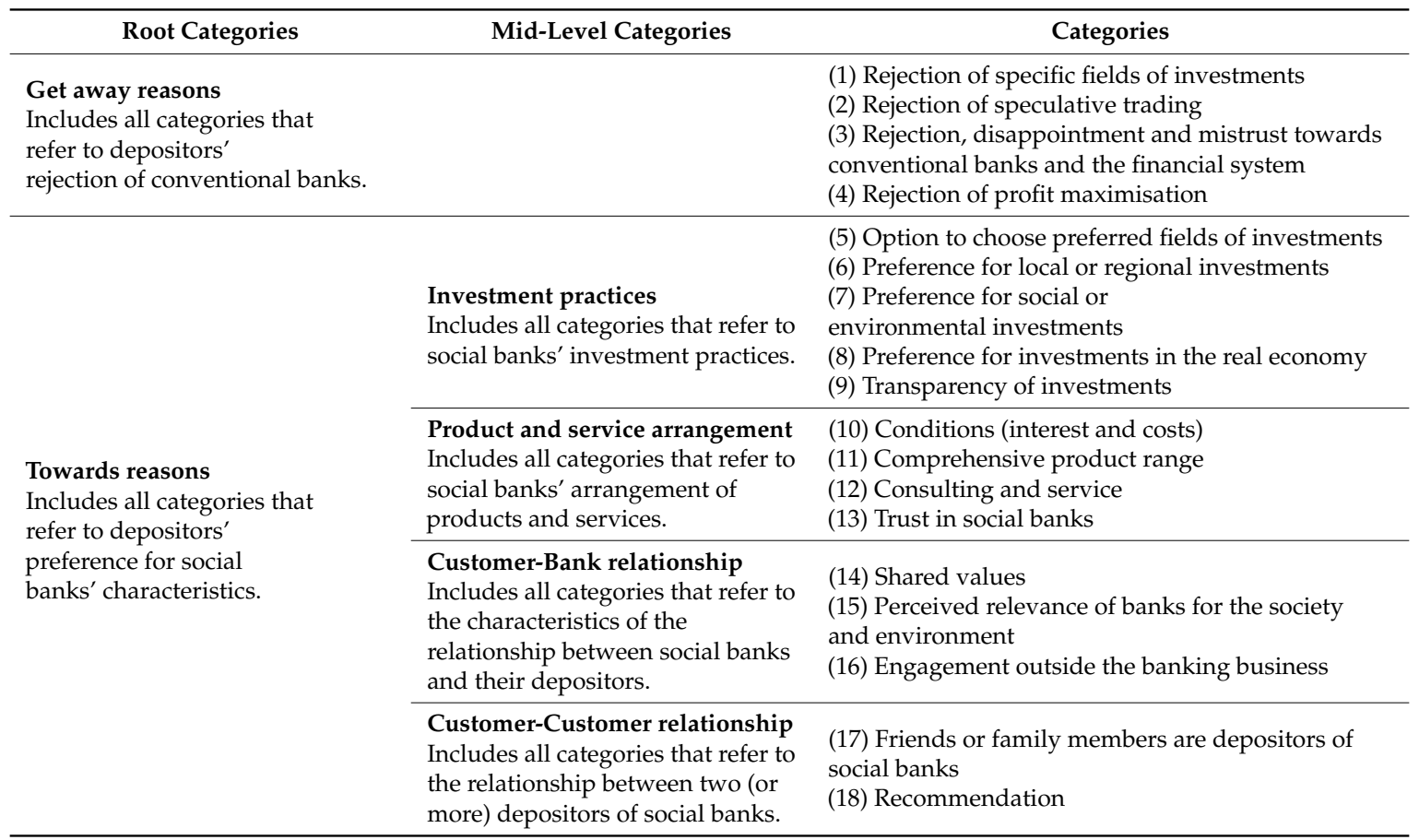

A comparison of the 18 reasons identified with the "ordinary" bank selection criteria (see Table 1) reveals high accordance. Most of the "Convenience", "Economic benefit", "Reputation", and "Service quality" aspects are included in the mid-level categories "Product and service arrangement" and "Customer-Customer relationship" (even if the level of aggregation is higher in the categories developed). These findings partially indicate that depositors have comparable reasons for choosing social and conventional banks, even if the spectrum of reasons for choosing social banks seems to be larger. Therefore, it is of great importance to investigate the individual relevance of reasons for choosing (social) banks to understand the real differences (or commonalities) in choosing social and conventional banks appropriately.

To ensure the reliability of the assignment to the root categories, two independent coders were asked to assign all reasons to the root and mid-level categories. In total, both test candidates assigned $97.22 \%$ of the categories to the category system, as shown in Table 4 . One coder assigned "Consulting and Service" to the mid-level category "Customer-Bank Relationship" instead of "Product and Service Arrangement". The high accordance of category assignment shows the clarity and accessibility of the category system. 


\section{Individual Relevance of Reasons for Choosing Social Banks}

The individual relevance of the 18 reasons for choosing social banks will be explored in this section. In this vein, depositors' reasons for choosing social banks are compared to those for conventional banks, to explore the differences between both groups. The identification of reasons with greater relevance, as well as of differences for choosing social and conventional banks, extend the implications of the previous section and provide relevant insights for the sound characterisation and differentiation of banks' customers.

\subsection{Data Collection}

An online survey of social and conventional depositors was used to collect the data required. The online survey was built using Questback (Unipark) software and distributed over personal and institutional networks and mailing lists, among others, including a German (mid-sized) university and the Institute for Social Banking, in January and February 2018. In July 2018, two German social banks promoted the survey via social media.

Respondents were asked to indicate which type of bank they hold deposits with. The survey differentiated between "social banks" and four types of conventional banks, including "church banks", "cooperative banks", "savings banks", and "private banks" (without using the term "conventional bank"). For each type of bank, respondents were able to name and describe multiple reasons in a text field, answering the question: "Why did you choose your bank?" Depositors were also asked to indicate the year in which they opened their account. In total, 108 social and 413 conventional depositors took part in the survey. The 413 conventional depositors held 463 accounts with conventional banks (four accounts with "church banks", 82 accounts with "cooperative banks", 183 with "savings banks", and 194 with "private banks"). The socio-demographic characteristics of both samples are presented in Table 5.

Table 5. Socio-Demographic Characteristics of the Samples.

\begin{tabular}{|c|c|c|c|c|}
\hline \multirow{2}{*}{ Variables } & \multicolumn{2}{|c|}{$\begin{array}{l}\text { Social Depositors } \\
\quad(n=108)\end{array}$} & \multicolumn{2}{|c|}{$\begin{array}{l}\text { Conventional Depositors } \\
\qquad(n=413)\end{array}$} \\
\hline & $n$ & $\%$ & $n$ & $\%$ \\
\hline \multicolumn{5}{|l|}{ Gender } \\
\hline Female & 45 & $43.7 \%$ & 187 & $46 \%$ \\
\hline Male & 58 & $56.3 \%$ & 217 & $54 \%$ \\
\hline \multicolumn{5}{|l|}{ Age (years) } \\
\hline Under 20 & 1 & $0.9 \%$ & 21 & $5 \%$ \\
\hline $20-29$ & 27 & $25.5 \%$ & 225 & $54 \%$ \\
\hline $30-39$ & 33 & $31.1 \%$ & 99 & $24 \%$ \\
\hline $40-49$ & 18 & $17.0 \%$ & 21 & $5 \%$ \\
\hline $50-59$ & 22 & $20.8 \%$ & 29 & $7 \%$ \\
\hline 60 or older & 5 & $4.7 \%$ & 18 & $4 \%$ \\
\hline \multicolumn{5}{|l|}{ Highest educational achievement } \\
\hline $\begin{array}{l}\text { No school qualifications, } \\
\text { or still at school }\end{array}$ & 0 & $0.0 \%$ & 1 & $0 \%$ \\
\hline $\begin{array}{l}\text { Secondary modern } \\
\text { school qualification }\end{array}$ & 0 & $0.0 \%$ & 1 & $0 \%$ \\
\hline Secondary school certificate & 8 & $7.7 \%$ & 15 & $4 \%$ \\
\hline University entrance qualification & 30 & $28.8 \%$ & 161 & $40 \%$ \\
\hline University degree & 60 & $57.7 \%$ & 183 & $45 \%$ \\
\hline Doctorate & 6 & $5.8 \%$ & 45 & $11 \%$ \\
\hline
\end{tabular}


Table 5. Cont.

\begin{tabular}{|c|c|c|c|c|}
\hline \multirow{2}{*}{ Variables } & \multicolumn{2}{|c|}{$\begin{array}{l}\text { Social Depositors } \\
\quad(n=108)\end{array}$} & \multicolumn{2}{|c|}{$\begin{array}{l}\text { Conventional Depositors } \\
\qquad(n=413)\end{array}$} \\
\hline & $n$ & $\%$ & $n$ & $\%$ \\
\hline \multicolumn{5}{|c|}{$\begin{array}{l}\text { Size of place of residence } \\
\text { (number of residents) }\end{array}$} \\
\hline Up to 5000 & 12 & $11.5 \%$ & 31 & $8 \%$ \\
\hline $5000-20,000$ & 10 & $9.6 \%$ & 14 & $3 \%$ \\
\hline $20,001-50,000$ & 8 & $7.7 \%$ & 18 & $4 \%$ \\
\hline $50,001-500,000$ & 38 & $36.5 \%$ & 297 & $74 \%$ \\
\hline More than 500,000 & 36 & $34.6 \%$ & 43 & $11 \%$ \\
\hline \multicolumn{5}{|c|}{ Individual net income (in $€$ ) } \\
\hline Up to 500 & 5 & $4.8 \%$ & 70 & $18 \%$ \\
\hline $500-1000$ & 12 & $11.5 \%$ & 117 & $29 \%$ \\
\hline $1001-1500$ & 17 & $16.3 \%$ & 56 & $14 \%$ \\
\hline 1501-2000 & 21 & $20.2 \%$ & 47 & $12 \%$ \\
\hline $2001-3000$ & 28 & $26.9 \%$ & 72 & $18 \%$ \\
\hline $3001-4000$ & 16 & $15.4 \%$ & 15 & $4 \%$ \\
\hline More than 4000 & 5 & $4.8 \%$ & 20 & $5 \%$ \\
\hline
\end{tabular}

Using Chi-Squared-Tests, a comparison of Sample 1 (social depositors) with the sample of Krause and Battenfeld's [22], which contains 2896 social depositors, reveals that both samples differ significantly (at least on a significance level of $p \leq 0.05$ ) for the "Highest educational achievement", "Size of place of residence", and "Individual net income". A visual inspection of observed and expected frequencies revealed the deviations that might explain these differences. Sample 1 does not include depositors with lower educational backgrounds at all, but depositors with a "University entrance qualification" to a higher degree. Inhabitants of small towns (20,001-50,000 inhabitants) seem to be slightly underrepresented, while inhabitants of larger cities $(50,001-500,000)$ are overrepresented. For "Individual net income", a larger proportion of depositors with higher (but still middle-class) incomes were found than expected. Some of these differences might be explained by the time differences in data collection. Krause and Battenfeld's [22] sample was collected in 2011, while the data used in this study was collected in 2018. It is quite possible that depositors with higher education backgrounds increased their incomes over a period of seven years, explaining the slightly higher depositor incomes in the present sample. Sample 1 thus might not appropriately represent social depositors with lower educational backgrounds, from smaller towns, and with lower incomes. However, since social depositors are generally expected to be highly educated, live in urban rather than in rural areas, and have middle-class incomes [22], the sample is expected to reflect the majority of social depositors appropriately.

With exception of the "Highest educational achievement", sample 2 (conventional depositors) shows an appropriate distribution of socio-demographic characteristics for a comparison group in an explorative setting. The sample does not include sufficient participants with lower educational backgrounds. However, since social depositors are generally more highly educated [22], social depositors are compared with their direct peers.

\subsection{Methodology}

Before the individual relevance of reasons for choosing social banks is analysed, the category system created in Section 3 (as fundament of the subsequent analyses) is reviewed based on the depositor data. Afterwards, using frequency analysis as a method of content analysis [42], two comparisons were conducted to explore the individual relevance of reasons for choosing social banks. Frequencies of codings per category of social depositors were compared with each other to identify reasons of superior relevance. The frequencies of codings per category were then compared between those of social and 
conventional depositors, in order to explore whether reasons for choosing a bank are of relevance for social depositors exclusively, or for the choice of banks in general.

Combining both qualitative and quantitative elements of analysis, content analysis enables the achievement of different objectives in one study, such as the creation of categories, the individual relevance of categories, and the variation of categories (factors) over time, based on frequencies of coding [42,45]). Majoch et al. [41] use content analysis in a comparable research approach to explore why investors sign the "Principles for Responsible Investment". They used "descriptive statistics (based on textual data) to demonstrate the importance of each factor and how it changed over time" [41] (p. 729).

To process the data from the online survey, depositors' self-stated reasons for choosing a bank were assigned to the category system developed in Section 3.3. As depositors were directly asked about their individual reasons for choosing their bank, no pre-selection of statements or data preparation was required. Gray et al. [46] usually recommend using one sentence as unit of analysis. However, if answers are weakly structured, multiple sentences or each participant's answer in total are reasonable alternatives. Both single words (e.g., "costs") and more complex answers (multiple sentences) could describe depositors' reasons for choosing social banks properly. Therefore, the unit of analysis is defined as the depositor's entire statement.

Since the category system was developed for social depositors' reasons for choosing social banks exclusively, not for the choice of conventional banks, it might not include all the relevant categories. However, as shown in Section 3.3, the 18 reasons identified accord to a high proportion with the 15 conventional bank selection criteria presented in Table 1 . It is therefore expected that all the relevant categories of conventional depositors' statements can be included. Nevertheless, statements that do not fit into the existing categories were collected for individual analyses. The initial coding of depositor reasons was executed by the author. Two independent coders assigned all the answers to the categories, to check the reliability of the initial coding.

\subsection{Results}

\subsubsection{Review of the Category System}

One hundred and eight social bank depositors answered the question concerning their individual reasons for choosing a social bank. The minimum codings per participant was one, and the maximum was five. Statements that have story-telling characteristics, such as "I got to know about ecological banks and switched directly", did not lead to a coding in the category system. However, none of the non-coded statements indicated a lack of reasons in the existing set of categories, supporting the completeness of the category system.

Depositors' answers led to 185 codings in 16 categories of the category system (see Table 6). The categories "Preference for local or regional investments" and "Preference for investments in the real economy" did not receive a coding. Both were allocated to the mid-level "Investment practices" category. Zero codings (from depositors) in a category did not necessarily indicate an overly extensive number of categories, but rather the minor relevance of these particular reasons (see Section 4.3.2). In this vein, a comparison of the number of expert codings reveals that both of these reasons also received just one or two codings from experts. As only two categories received zero codings from depositors, the category system does not seem to be inefficiently overloaded with needless categories either.

The individual intercoder reliability for social depositors' statements only was calculated, indicating an "almost perfect" (82.28\%) accordance of the assignment of social depositor reasons. Since three coders allocated $82.28 \%$ of all codings to the same category, the clarity and accessibility of the system also seems to be appropriate. To summarise, the results indicate that the category system created based on data from experts seems to be complete, not overloaded, clear, and easy to access. The system of categories is thus expected to be able to build an appropriate foundation for the subsequent analyses. 
Table 6. Variation of Codings per Category over Time.

\begin{tabular}{|c|c|c|c|c|c|c|c|c|c|c|}
\hline \multirow{2}{*}{$\begin{array}{l}\text { Category } \\
\text { Get away reasons }\end{array}$} & \multicolumn{2}{|c|}{ Social Banks } & \multicolumn{2}{|c|}{ All Conventional Banks } & \multicolumn{2}{|c|}{ Coop. Banks } & \multicolumn{2}{|c|}{ Savings Banks } & \multicolumn{2}{|c|}{ Private Banks } \\
\hline & 52 & $28 \%$ & 30 & $4 \%$ & 5 & $4 \%$ & 6 & $2 \%$ & 19 & $7 \%$ \\
\hline Rejection of specific fields of investments a & 30 & $16 \%$ & 0 & $0 \%$ & 0 & $0 \%$ & 0 & $0 \%$ & 0 & $0 \%$ \\
\hline Rejection of speculative trading a & 6 & $3 \%$ & 1 & $0 \%$ & 0 & $0 \%$ & 1 & $0 \%$ & 0 & $0 \%$ \\
\hline Rejection, disappointment and mistrust towards other banks $[\ldots]^{\mathrm{a}, \mathrm{b}}$ & 15 & $8 \%$ & 29 & $4 \%$ & 5 & $4 \%$ & 5 & $2 \%$ & 19 & $7 \%$ \\
\hline Rejection of profit maximisation & 1 & $1 \%$ & 0 & $0 \%$ & 0 & $0 \%$ & 0 & $0 \%$ & 0 & $0 \%$ \\
\hline Towards reasons & 133 & $72 \%$ & 664 & $96 \%$ & 123 & $96 \%$ & 269 & $98 \%$ & 272 & $93 \%$ \\
\hline Investment practices & 75 & $41 \%$ & 21 & $3 \%$ & 11 & $9 \%$ & 10 & $4 \%$ & 0 & $0 \%$ \\
\hline Option to choose preferred fields of investments a & 4 & $2 \%$ & 0 & $0 \%$ & 0 & $0 \%$ & 0 & $0 \%$ & 0 & $0 \%$ \\
\hline Preference for local or regional investments & 0 & $0 \%$ & 13 & $2 \%$ & 4 & $3 \%$ & 9 & $3 \%$ & 0 & $0 \%$ \\
\hline Preference for social or environmental investments ${ }^{a}$ & 52 & $28 \%$ & 6 & $1 \%$ & 6 & $5 \%$ & 0 & $0 \%$ & 0 & $0 \%$ \\
\hline Preference for investments in the real economy & 0 & $0 \%$ & 1 & $0 \%$ & 0 & $0 \%$ & 1 & $0 \%$ & 0 & $0 \%$ \\
\hline Transparency of investments ${ }^{a}$ & 19 & $10 \%$ & 1 & $0 \%$ & 1 & $1 \%$ & 0 & $0 \%$ & 0 & $0 \%$ \\
\hline Product and service arrangement & 11 & $6 \%$ & 458 & $66 \%$ & 65 & $51 \%$ & 158 & $57 \%$ & 235 & $81 \%$ \\
\hline Conditions (interest and costs) ${ }^{a}$ & 6 & $3 \%$ & 205 & $30 \%$ & 32 & $25 \%$ & 46 & $17 \%$ & 127 & $44 \%$ \\
\hline Comprehensive product range ${ }^{\text {a }}$ & 1 & $1 \%$ & 189 & $27 \%$ & 22 & $17 \%$ & 79 & $29 \%$ & 88 & $30 \%$ \\
\hline Consulting and service ${ }^{a}$ & 4 & $2 \%$ & 64 & $9 \%$ & 11 & $9 \%$ & 33 & $12 \%$ & 20 & $7 \%$ \\
\hline Customer-Bank relationship & 42 & $23 \%$ & 34 & $5 \%$ & 18 & $14 \%$ & 13 & $5 \%$ & 3 & $1 \%$ \\
\hline Trust in bank ${ }^{b}$ & 2 & $1 \%$ & 12 & $2 \%$ & 2 & $2 \%$ & 7 & $3 \%$ & 3 & $1 \%$ \\
\hline Shared values ${ }^{\text {a }}$ & 33 & $18 \%$ & 15 & $2 \%$ & 14 & $11 \%$ & 1 & $0 \%$ & 0 & $0 \%$ \\
\hline Perceived relevance of banks for the society and environment ${ }^{a}$ & 5 & $3 \%$ & 0 & $0 \%$ & 0 & $0 \%$ & 0 & $0 \%$ & 0 & $0 \%$ \\
\hline Engagement outside the banking business & 2 & $1 \%$ & 7 & $1 \%$ & 2 & $2 \%$ & 5 & $2 \%$ & 0 & $0 \%$ \\
\hline Customer-Customer relationship & 5 & $3 \%$ & 151 & $22 \%$ & 29 & $23 \%$ & 88 & $32 \%$ & 34 & $12 \%$ \\
\hline Friends or family members are depositors ${ }^{a, b}$ & 1 & $1 \%$ & 144 & $21 \%$ & 28 & $22 \%$ & 87 & $32 \%$ & 29 & $10 \%$ \\
\hline Recommendation & 4 & $2 \%$ & 7 & $1 \%$ & 1 & $1 \%$ & 1 & $0 \%$ & 5 & $2 \%$ \\
\hline Total & 185 & $100 \%$ & 694 & $100 \%$ & 128 & $100 \%$ & 275 & $100 \%$ & 291 & $100 \%$ \\
\hline
\end{tabular}

Notes: a Chi-Squared-Tests (or Fisher's exact test respectively) show significant differences in codings per category between social and conventional depositors on a level of at least $p \leq 0.01$;

${ }^{\mathrm{b}}$ Category name was adjusted to the wider spectrum of bank types. 


\subsubsection{Identification of the Relevance of Reasons}

A comparison of reasons for choosing social banks revealed that five categories clearly had more codings than the others. These categories are: "Preference for social and environmental investments" (28\% of codings), "Shared values" (18\%), "Rejection of specific fields of investments" $(16 \%)$, "Transparency of investments" (10\%), and "Rejection, disappointment and mistrust towards conventional banks and the financial system" ( $8 \%$ ) (see Table 6). Provided that "within content-analytical category systems, registration of how often a category occurs (frequency of coding) may give added weight to its meaning and importance" [42] (p. 41), the larger numbers of codings in these five categories might indicate a higher relevance for depositors' choice of social banks.

The numbers of codings from experts support this assumption. All five categories are among the six most-stated reasons by experts (see Table 3). These findings support previous assumptions that social banks' investment selection is the most relevant reason for the choice of social banks. However, the findings also reveal the relevance of other reasons, such as "Shared values" or the "Rejection, disappointment and mistrust towards conventional banks and the financial system".

"Rejection of profit maximization", "Preference for local or regional investments", "Preference for investments in the real economy", "Comprehensive product range", "Trust in social banks", "Engagement outside the banking business", and "Friends or family members are depositors of social banks" had only zero to two codings from social depositors, indicating a limited relevance to depositors' choice of social banks. A comparison of these coding results with the numbers of codings from experts (see Table 3) shows that these categories also received comparably low numbers from experts, supporting the expected minor relevance for depositor decision-making. However, it does not seem to be reasonable to expect that the majority of social depositors do not trust social banks, but rather seems to be a matter of course for most depositors. A low number of codings could thus also be an indicator of implicit reasons, which cannot be collected appropriately in this qualitative research design.

\subsubsection{Comparison of Reasons for Choosing Social and Conventional Banks}

The comparison of social and conventional bank depositors reveals further insights that are relevant to the identification of the relative relevance of reasons for choosing social banks. In total, 413 conventional depositors answered the questionnaire, leading to 694 codings in the category system. Statements that do not answer the question appropriately were excluded from category allocation. Twelve statements were not able to be categorised, describing reasons not included in the system of categories. However, these statements reflect just $1.7 \%$ of all codings from conventional depositors and very special cases, such as "being an employee of the bank" or "inheritance". Therefore, it is expected that the focus of the category system on social depositors does not infringe the reliability of this comparison. The number of codings from church bank depositors was too low for further analysis (4 accounts with 7 codings) and was thus excluded from the following argumentation. Based on the assignment of (all) statements by two independent coders, an intercoder reliability of $88.88 \%$ was calculated, indicating an "almost perfect" accordance [44]. This high level of accordance most likely results from the high number of very clear statements from conventional depositors concerning the categories "Conditions (interest and costs)", "Comprehensive product range", "Consulting and service", and "Friends or family members are depositors [ ... ]".

The coding results directly support the importance of "Convenience", "Economic benefit", "Reputation" and "Service quality" to conventional depositors' bank selection. Sixty-six percent of all codings from conventional depositors were categorised in the mid-level category "Product and service arrangement" (see Table 6). Besides low fees, higher rates of interest, and the access to ATMs and bank branches, friends and family members are important reasons for the choice of conventional banks, especially for customers of cooperative and savings banks. In total, an average of $87 \%$ of the statements from conventional depositors were clustered in "Product and service arrangement" and "Friends or family members are depositors", indicating a very concentrated spectrum of reasons for 
choosing conventional banks. By contrast, just $7 \%$ of statements from social depositors were allocated to these categories. While $92 \%$ of all codings from social depositors were allocated to "get away" reasons, "Investment practices", and "Customer-Bank relationship", cooperative banks received just $27 \%$, savings banks $11 \%$, and private banks $9 \%$ of all codings in these categories. These findings indicate that the reasons for choosing social banks might basically differ from the reasons for choosing conventional banks. Chi-Squared-Tests (or Fisher's exact tests, for expected cell frequencies below 5) show that the codings per category differ significantly between social and conventional depositors in twelve of the eighteen categories, including all categories that seem to be predominantly relevant for social or conventional depositors (see Table 6).

In summary, the findings indicate that five reasons for choosing social banks might be of greater relevance for depositors' decision-making, and that these reasons differ from reasons for choosing conventional banks. While conventional depositors might choose banks due to the "Product and service arrangement" or friends and family members, social depositors seem to predominantly choose social banks due to "Rejection of specific fields of investments", "Rejection, disappointment and mistrust towards conventional banks and the financial system", "Preference for social or environmental investments", "Transparency of investments", and "Shared values". The identification of important and unique reasons for choosing a social bank provides a qualitative characterisation of the customers.

\section{Development of Social Bank Customer Groups}

The global financial crisis is considered to be significant to the rise of social banks [6-8]. However, it remains unclear how the global financial crisis has affected depositors' reasons for choosing social banks and social banks' growth (of deposits). Two of the expert statements in Section 3.3 imply that the global financial crisis might lead to an extension of social banks' customer target groups, who differ in their reasons for choosing social banks. The development of social bank customer groups over time will thus be explored in this section. The exploration of customer group development could provide an initial, empirically derived explanation for social banks' growth in the aftermath of the global financial crisis. Furthermore, the findings could support social banks' marketing by identifying discriminative communication strategies for specific customer target groups.

\subsection{Methodology}

Data needed for the formation of customer groups comes from the 108 social depositors described in Section 4.2. Depositors are classified using Ward's hierarchical cluster analysis, with squared Euclidean distances based on the binary coded self-stated reasons (18 categories). Cluster analysis is an explorative research method that has frequently been used in economic research to classify people or objects, such as customer target groups [47,48], enabling institutions to create discriminative marketing strategies [49]. The purpose of the present cluster analysis is the identification of few and homogeneous clusters of depositors. Therefore, the number of clusters is determined by the lowest number of highly homogenous and discriminative clusters. In this vein, the elbow method is used to identify a suitable number of clusters. After classification, each clustered depositor was recorded in a timeline of account opening dates, enabling a visual inspection of the variation in customer groups (clusters) over time.

\subsection{Results}

In total, six clusters of depositors were identified based on the binary coded reasons for choosing a social bank. Table 7 shows the distribution of depositors to the clusters, as well as the constellations of reasons that characterise the clusters. 
Table 7. Customer Groups of Social Banks.

\begin{tabular}{|c|c|c|c|c|}
\hline Cluster Name & $\begin{array}{l}\text { No. of Depositors } \\
\text { (No. of Codings) }\end{array}$ & Coding Categories in Cluster & $\begin{array}{l}\text { Proportion of Codings } \\
\text { in Cluster }\end{array}$ & $\begin{array}{l}\text { Proportion of Depositors with } \\
\text { Coding in Cluster }\end{array}$ \\
\hline \multirow{4}{*}{ Value centred } & \multirow{4}{*}{$32(49)$} & Preference for social or environmental investments & $12 \%$ & $19 \%$ \\
\hline & & Conditions (interest and costs) & $10 \%$ & $16 \%$ \\
\hline & & Shared values & $51 \%$ & $78 \%$ \\
\hline & & Other: $2,3,4,11,12,13,15,18$ & $26 \%$ & - \\
\hline \multirow{2}{*}{ Impact investment centred } & \multirow{2}{*}{$22(24)$} & Preference for social or environmental investments & $92 \%$ & $100 \%$ \\
\hline & & Other: 2,16 & $8 \%$ & - \\
\hline \multirow{4}{*}{ Transparency centred } & \multirow{4}{*}{$16(35)$} & Rejection of specific fields of investments & $9 \%$ & $19 \%$ \\
\hline & & Preference for social or environmental investments & $26 \%$ & $56 \%$ \\
\hline & & Transparency of investments & $46 \%$ & $100 \%$ \\
\hline & & Other: $5,10,14,18$ & $20 \%$ & - \\
\hline \multirow{4}{*}{ Impact and exclusion mix } & \multirow{4}{*}{$10(27)$} & Rejection of specific fields of investments & $37 \%$ & $100 \%$ \\
\hline & & Option to choose preferred fields of investments & $11 \%$ & $30 \%$ \\
\hline & & Preference for social or environmental investments & $37 \%$ & $100 \%$ \\
\hline & & Other: $2,9,13,15$ & $16 \%$ & - \\
\hline \multirow{4}{*}{ Conventional bank rejection mix } & \multirow{4}{*}{$11(23)$} & $\begin{array}{l}\text { Rejection, disappointment and mistrust towards } \\
\text { conventional banks }[\ldots]\end{array}$ & $48 \%$ & $100 \%$ \\
\hline & & Preference for social or environmental investments & $17 \%$ & $36 \%$ \\
\hline & & Consulting and service & $9 \%$ & $18 \%$ \\
\hline & & Other: $9,14,16,17$ & $26 \%$ & - \\
\hline \multirow{4}{*}{ Exclusion centred } & \multirow{4}{*}{$17(27)$} & Rejection of specific fields of investments & $63 \%$ & $100 \%$ \\
\hline & & Rejection of speculative trading & $6 \%$ & $18 \%$ \\
\hline & & Rejection, disappointment and mistrust towards & $6 \%$ & $18 \%$ \\
\hline & & $\begin{array}{c}\text { Conventional banks }[\cdots] \\
\text { Other: } 7,12,14\end{array}$ & $8 \%$ & - \\
\hline
\end{tabular}


Five of the six clusters are characterised by one or two reasons, which were stated by each depositor of the cluster. Only the "Value centred" cluster shows a slightly wider distribution of reasons. However, since approximately $80 \%$ of depositors included stated "Shared values" as a reason for choosing a social bank, the cluster seems to be characterised sufficiently in this explorative context, even though some residuals might be included. An increase in the number of clusters led to the exclusion of these residuals, but to the creation of very small clusters. Figure 1 illustrates the proportions of "towards" and "get away" reasons among the six clusters. Three clusters predominantly consist of "towards" reasons and one cluster of "get away" reasons. The remaining two clusters show a strong mix of "towards" and "get away" reasons.

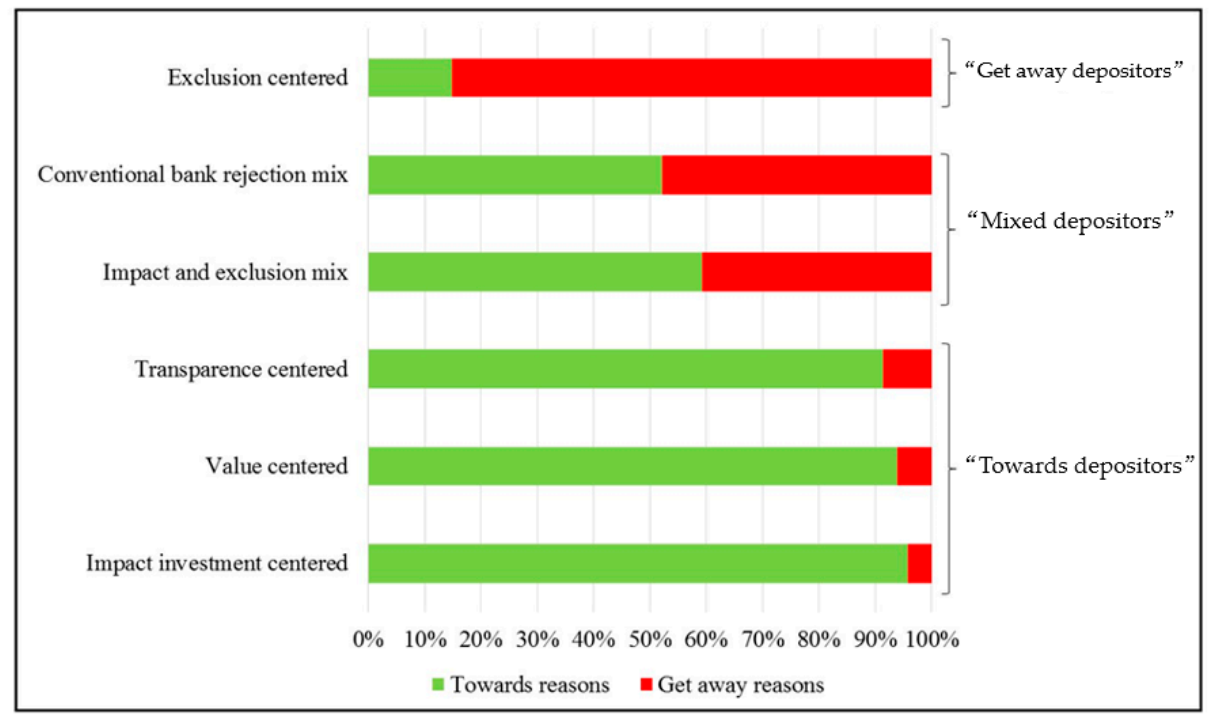

Figure 1. Distribution of Codings in Depositor Clusters.

The classification of social depositors allows for an inspection of the development of customer groups over time. Figure 2 shows the number of depositors per customer group between 2000 and 2019. As explained in Section 4.2, customers were classified based on their categorised reasons for choosing social banks. Cumulated numbers of depositors are used to show customer group proportions for each year. To ease the accessibility of the figure, the three "towards depositor" clusters are illustrated in variants of green, "mixed depositors" in yellow and orange, and "towards depositors" in red.

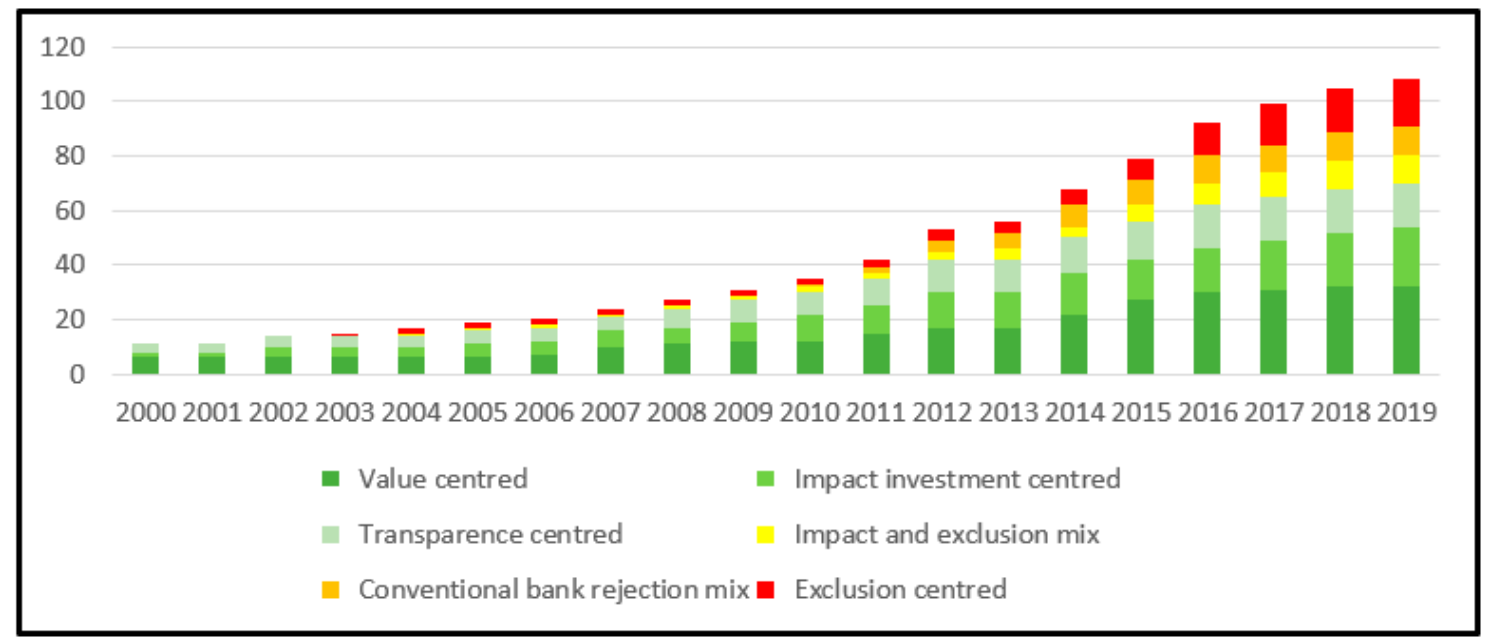

Figure 2. Development of Social Banks' Customer Groups (Cumulated 2000-2019). 
Until 2002, only "towards depositors" (all three clusters) were found in the present sample, supporting expert's expectation that "at the beginning of the social banking movement, the need to do something positive in a specific sector was maybe stronger" (see Section 3.3). However, the development of "Value centred", "Impact investment centred", and "Transparency centred" customers (approximately 65\% of all depositors in 2019) implies that the growth of social banks' deposits might not merely be caused by the increase of "mixed" and "get away customers", but by the (absolute) increase of "towards customers" as well.

In 2003 and 2004, the first "Exclusion centred" and "Impact and exclusion mix" customers were found, indicating that negative push effects from conventional towards social banks had already appeared before the global financial crisis of 2007. Social depositors' rejection of negative investments thus does not seem to have originally been triggered by the global financial crisis. However, the proportion of "Exclusion centred" and "Impact and exclusion mix" customers in the sample had grown up to $25 \%$ by 2019 , illustrating a strong relative increase of relevance for the growth in the deposits of social banks.

The first "Conventional bank rejection mix" depositors were found in 2010. Their proportion in the sample had grown up to approximately $10 \%$ by 2019 . These findings indicate that the global financial crisis might have triggered a new customer group to switch to a social bank. This customer group is predominantly characterised by the "Rejection, disappointment and mistrust towards conventional banks and the financial system", which could suit a crisis explanation for the growth of social banks.

In summary, it seems that the proportion of "get away customers" has been increasing since 2007, indicating that the global financial crisis might helped social banks' growth through depositors who choose social banks because of conventional banks' "evil" characteristics. However, two-thirds of the depositors in the sample are clustered in one of three "towards customer" groups, which all grew until 2019 as well, indicating that the shift from "towards" to "get away" (or "mixed") customers might not be as strong as expected. The global financial crisis thus might be not the only factor that supported social banks' growth over the past years. If the crisis had an effect on social banks' deposit growth, the present results may indicate mixed effects on the "get away" and "mixed customer" groups. While the development of "Exclusion centred" and "Impact and exclusion mix" customers might "merely" have been boosted by the global financial crisis, "Conventional bank rejection mix" depositors could really have been triggered by this intervention. These findings create an initial, empirically derived explanation for some social banks' growth in the aftermath of the global financial crisis, and a sound characterisation of customer groups that enable social banks' marketing departments to set discriminative communication strategies.

\section{Discussion}

\subsection{Research Implications}

This study explored 18 depositor reasons for choosing social banks and transferred this set of reasons into a structured, multi-level category system that refers to social banks' "good" and conventional banks' "evil" characteristics. Several of these reasons have been unknown or inaccurately described until now. Previous research on (conventional) depositor bank choices provided 15 reasons in total [29]. The present findings enlarge this set of reason by multiple new aspects, in particular regarding social and environmental issues. In light of increasing sustainability awareness, these aspects could also be relevant for conventional banks in the future. The few previous research attempts at investigating depositors' choice of social banks [10,22,29] predominantly focus on reasons that refer to (expected) core differences to conventional banks: asset placement, level of transparency (concerning the placement of assets), and the possibility of customer participation $[8,23]$. The present results add multiple important reasons, such as "Shared Values" or "Rejection, disappointment and mistrust towards conventional banks and the financial system". While previous studies have expected social banks' placement of assets to be one of the main reasons for choosing social banks [7-10,22], 
the present results specify this general assumption by identifying at least seven dimensions (categories) of this reason, allowing for a much more specific investigation of customer preferences. Five reasons were identified as being of more potential relevance to depositor decision-making. These reasons for choosing social banks seem to differ from those for choosing conventional banks in general. This study provides the first comprehensive comparison of bank selection reasons for social and conventional depositors. The observation of customer group development over time indicates that the global financial crisis might have helped social banks' growth of deposits by an extension in customer groups that choose social banks because of conventional banks' "evil" characteristics. While previous studies stated that the global financial crisis is relevant to social banks' growth [6-8], no study has yet provided an approach to explaining how the financial crisis has affected social banks growth. These findings have diverse implications.

The exploration of a comprehensive set of depositor reasons enables subsequent research to investigate reasons for choosing social banks in a more comprehensive way. In particular, the findings have paved the way for (1) a conjoint analysis in an experimental setting to investigate the relative importance of the 18 reasons for choosing social banks and (2) more comprehensive comparisons of social and conventional depositors' preferences, including the 18 reasons.

The set of reasons indicates that some depositors may choose social banks because of social banks' "good" characteristics, others because of conventional banks' "evil" characteristics. Especially in industries such as commercial banking, where a switch from one to another bank is associated with high costs [50], a negative push effect (towards social banks), for instance caused by the financial crisis, is considered to be of vital importance. This assumption finds theoretical backup in consumer behaviour research on the negativity bias, considering that a "bad" event, such as a global financial crisis, has a stronger impact on behaviour than "good" ones [30,31]. Subsequent research is thus encouraged to investigate the effect of negative interventions on customer behaviour in the light of high switching barriers. Since Bayer et al. [29] argue that emotional charging of the topic of social banking could increase depositor demand for social banks, it would be of great interest to see whether "get away" reasons could overcome intention behaviour gaps by creating sufficient emotional charge.

The investigation of the development of customer groups indicates that the global financial crisis might extend social banks' customer target groups by "Conventional bank rejection mix" depositors. The relation of a banking-centred financial crisis with the "Rejection, disappointment and mistrust towards conventional banks and the financial system" seems to be generally comprehensible. Interestingly, the findings further reveal that "Exclusion centred" and "Impact and exclusion mix" customers appeared before the global financial crisis, indicating that the global financial crisis does not seem to be the originally trigger for these customer groups. Since both groups have grown massively over the past one and a half decade, the global financial crisis could "only" be a relevant booster. However, the "get away" reasons that characterise both clusters fit the characteristics of the global financial crisis insufficiently. The crisis was driven by profit-orientated speculation on structured financial products in the US housing market, not by banks' investments in specific fields like nuclear energy, fossil fuels, or weapons. However, both customer groups are predominantly characterised by the "Rejection of specific fields of investments". If the global financial crisis really had an effect on the growth of these customer groups, it must thus be a mediated effect. The global financial crisis could have led to a stronger discourse concerning banking preferences among depositors. Based on this, depositors might find a better match for their preferences with social banks. Subsequent research should thus investigate the complex relation of crisis characteristics with depositors' choice of social banks, using structural equation models in an experimental research setting.

Since the banking industry-centred global financial crisis seems to had a direct and (potentially) mediated effect on depositors' choice of social banks, it is not expected that the current COVID-19 pandemic and its economic impact will lead to a comparable boost in new deposits for social banks based on customer decisions that have not been forced. Unlike the global financial crisis, the current crisis does not have its roots in the general issues of the global financial system, including banks. 
It does not seem reasonable to expect that private depositors will start to rethink their choice of bank during times at which issues other than sustainability (in banking) dominate public debate. However, if some conventional banks do go bankrupt due to the consequences of the COVID-19 pandemic, their depositors will be forced to choose a new bank. This might lead to a short-term increase in social depositors, because depositors could be forced to "pay" the high transaction cost of switching to a new bank anyway. If such cases do appear, subsequent research attempts should investigate this new stream of depositors to give valuable insights into the effect of lower switching costs on depositors' choice of social banks, based on real market data.

Due to the explorative character of this study, it remains unclear to which proportion social depositors consist of "get away", "mixed", and "towards" customers. Since the global financial crisis could have different effects on social bank customer groups, the concrete impact of the global financial crisis on social banks' entire growth also remains unclear. To quantify a crisis effect, subsequent research is encouraged to investigate the proportion of social banks' customer groups, using larger samples in quantitative settings.

\subsection{Practical Implications}

The practical implications of the present study are of relevance for social banks' marketing and for conventional banks, which aim to adapt the principles of social banks. Social banks still have growth potential [22]. Bayer et al. [29] identified several factors, which discourage potential depositors from selecting a social bank. These factors are a lack of information, limited pressure in the social context, weak moral intensity, and economical sacrifices. The authors suggest that more factual information and emotional charging of social banking could increase depositor demand for social banks. The present results help social banks' marketing identify appropriate topics for creating contemporary, factual information and emotional charging for specific customer target groups.

While cooperative, savings, and private banks all seem to compete for cheapest fees, highest rates of interest, and most attractive range of products and services, social banks attract depositors with exclusive reasons. Social banks are thus able to concentrate on their unique selling propositions that are hard to claim by competitors, such as their investment selection, the high level of transparency, or applied examples of their values.

The findings show that "get away customers" have also switched to social banks in recent years. The distinction from economic (mis-) behaviour that may be associated with conventional banks, such as speculative trading, pure focus on profit maximisation, and investments with negative impact, thus still seems to be a relevant topic for social banks' communication strategies. As switching banks is associated with high costs for the depositor [50], push reasons with emotional charging through illustrating absence of social and environmental harm might be of great relevance for initiating customer action.

Höhnke and Homölle [10] showed that some social banks merely invest in projects with a positive social or environmental impact (impact investment strategy), whereas other social banks only exclude negative projects (exclusion strategy). The present results indicate that "Preference for social and environmental investments" and "Rejection of specific fields of investments" are of relevance for depositors' choice of social banks. Both investment strategies attract relevant customer groups. However, while the first type of social banks necessarily fulfil the preferences of "Impact investment centred", "Impact and exclusion mix", and "Exclusion centred" customers, the second type might attract "Exclusion centred" customers only. Attracting customers through the misbehaviour of competitors does not seem to be a self-determined and sustainable long-term strategy. Social banks, which conduct the exclusion strategy, are thus encouraged to pay special attention to other important reasons for choosing social banks, such as "Transparency of investments" and "Shared values", in order to extend their customer target groups.

Besides implications for existing social banks, the present results provide relevant implications for (former) conventional banks, which started to adopt the principles of social banks. In recent 
years, three (formerly) conventional banks in Germany started to adopt investment criteria for their selection of financial assets, comparable to those of social banks (Raiffeisenbank Holzkirchen-Otterfing in 2014, Evenord-Bank in 2015, and Deutsche Kreditbank in 2019). Höhnke and Homölle [10] conclude that the future growth of the social banking movement could be carried by the transformation of conventional banks. The present results are the first overview of a comprehensive range of depositor reasons for choosing social banks and are thus a benchmark for adapting conventional banks. The present findings support the importance of investment selection criteria for the choice of social banks, since "Preference for social and environmental investments" and "Rejection of specific fields of investments" are considered to be more important for social depositors. However, "Shared values", "Rejection, disappointment and mistrust towards conventional banks and the financial system", and "Transparency" seem to be of great importance to social depositors as well, since all three reasons are the predominant character of three customer groups, which form approximately $55 \%$ of the present sample. These findings indicate that the transformation process from a conventional to a social bank, which attracts the entire spectrum of customer groups, could be much more complex than "just" introducing investment criteria. Therefore, based on the identification of reasons for choosing social banks, adapting conventional banks are encouraged to develop and disclose (1) a clear mission statement that presents the bank's core objectives and values, (2) precise investment criteria to describe the bank's selection of investments, and (3) information about their use of funds to prove compliance of their objectives and values with the work applied.

\subsection{Limitations}

Four out of nine experts in this study were private customer account managers of social banks. Furthermore, five managers of social banks took part in the banking survey and answered the question concerning depositor reasons for choosing social banks. In total, $64 \%$ of the sample were employees or managers of social banks, which could lead to a positivity bias. However, a comparison of experts' answers show that 13 out of 18 categories were also addressed by independent academic and market experts. The additional five categories that were merely addressed by employees or managers of social banks were "Recommendation", "Engagement outside the banking business", "Option to choose preferred fields of investments", "Consulting and service", and "Conditions (interest and costs)". Since each of these categories actually received two to six codings from depositors as well (see Table 6), the selection of experts does not seem to infringe upon the reliability of results.

Depositor answers could be biased by the time between their choice of a social bank and their participation in the online survey (recency bias). The "oldest" social depositor opened his bank account in 1970 and answered the survey in 2018. Depositor answers could thus reflect their current personal perspective (affected by different events over time) more than their original reasons for choosing a social bank. However, the potential bias is not expected to infringe upon the results in general. Assuming the reputation of conventional banks and the entire financial industry have suffered over the past two decades, e.g., because of the global financial crisis [51-53], a time-related bias would most likely lead to a greater amount of codings in the "get away" reason categories, even if depositors initially chose social banks for "towards" reasons. As shown in Table 8, only a few "get away" reasons were coded in the pre-crisis group, indicating a low potential of time-related bias in the answers.

Instead, approximately $48 \%$ of depositors in the crisis and post-crisis groups (representing approximately $34 \%$ of the sample) stated at least one "get away" reason, indicating a higher potential of a time-related bias. However, sufficient "get away" reasons were also found in the last years of the observation. If depositors who opened a bank account short before participating in the online survey stated "get away" reasons, a time-related bias does not seem to drive the rise of "get away" reasons in the aftermath of the global financial. Furthermore, the coding results of depositors' self-stated reasons basically accord with experts' expectations concerning the development of depositor reasons for choosing social banks (see Section 3.3.). 
Table 8. Variation of Codings per Category over Time.

\begin{tabular}{|c|c|c|c|c|c|c|}
\hline \multirow{2}{*}{$\begin{array}{l}\text { Category } \\
\text { Get away reasons }\end{array}$} & \multicolumn{2}{|c|}{ All } & \multicolumn{2}{|c|}{ Until 2007} & \multicolumn{2}{|c|}{ Since 2008} \\
\hline & 52 & $28 \%$ & 4 & $11 \%$ & 48 & $32 \%$ \\
\hline Rejection of specific fields of investments & 30 & $16 \%$ & 3 & $9 \%$ & 27 & $18 \%$ \\
\hline Rejection of speculative trading & 6 & $3 \%$ & 1 & $3 \%$ & 5 & $3 \%$ \\
\hline $\begin{array}{l}\text { Rejection, disappointment and mistrust } \\
\text { towards }[\ldots]\end{array}$ & 15 & $8 \%$ & 0 & $0 \%$ & 15 & $10 \%$ \\
\hline Rejection of profit maximisation & 1 & $1 \%$ & 0 & $0 \%$ & 1 & $1 \%$ \\
\hline Towards reasons & 133 & $72 \%$ & 31 & $89 \%$ & 102 & $68 \%$ \\
\hline Investment practices & 75 & $41 \%$ & 17 & $49 \%$ & 58 & $39 \%$ \\
\hline $\begin{array}{l}\text { Option to choose preferred fields } \\
\text { of investments }\end{array}$ & 4 & $2 \%$ & 1 & $3 \%$ & 3 & $2 \%$ \\
\hline Preference for local or regional investments & 0 & $0 \%$ & 0 & $0 \%$ & 0 & $0 \%$ \\
\hline $\begin{array}{l}\text { Preference for social or } \\
\text { environmental investments }\end{array}$ & 52 & $28 \%$ & 11 & $31 \%$ & 41 & $27 \%$ \\
\hline Preference for investments in the real economy & 0 & $0 \%$ & 0 & $0 \%$ & 0 & $0 \%$ \\
\hline Transparency of investments & 19 & $10 \%$ & 5 & $14 \%$ & 14 & $9 \%$ \\
\hline Product and service arrangement & 11 & $6 \%$ & 2 & $6 \%$ & 9 & $6 \%$ \\
\hline Conditions (interest and costs) & 6 & $3 \%$ & 1 & $3 \%$ & 5 & $3 \%$ \\
\hline Comprehensive product range & 1 & $1 \%$ & 1 & $3 \%$ & 0 & $0 \%$ \\
\hline Consulting and service & 4 & $2 \%$ & 0 & $0 \%$ & 4 & $3 \%$ \\
\hline Customer-Bank relationship & 42 & $23 \%$ & 12 & $34 \%$ & 30 & $20 \%$ \\
\hline Trust in social banks & 2 & $1 \%$ & 0 & $0 \%$ & 2 & $1 \%$ \\
\hline Shared values & 33 & $18 \%$ & 11 & $31 \%$ & 22 & $15 \%$ \\
\hline $\begin{array}{l}\text { Perceived relevance of banks for the society } \\
\text { and }[\ldots]\end{array}$ & 5 & $3 \%$ & 1 & $3 \%$ & 4 & $3 \%$ \\
\hline Engagement outside the banking business & 2 & $1 \%$ & 0 & $0 \%$ & 2 & $1 \%$ \\
\hline Customer-Customer relationship & 5 & $3 \%$ & 0 & $0 \%$ & 5 & $3 \%$ \\
\hline $\begin{array}{l}\text { Friends or family members are depositors of } \\
\text { social banks }\end{array}$ & 1 & $1 \%$ & 0 & $0 \%$ & 1 & $1 \%$ \\
\hline Recommendation & 4 & $2 \%$ & 0 & $0 \%$ & 4 & $3 \%$ \\
\hline Total Number of Codings & 185 & $100 \%$ & 35 & $100 \%$ & 150 & $100 \%$ \\
\hline Number of Depositors & \multicolumn{2}{|c|}{108} & \multicolumn{2}{|c|}{24} & \multicolumn{2}{|c|}{84} \\
\hline
\end{tabular}

The classification of social bank customer groups was based on the binary coded reasons of social depositors. This simple data structure does not provide information about the individual priority of reasons. The present cluster analysis assumed equal relevance for all the stated reasons of a depositor. This assumption might lead to the incorrect classification of depositors and, in turn, to an infringement on the results. Generally, a very simple form of cluster analysis and data structure was used in the present study. Due to binary coded variables and the relatively small sample size, a split-sample or two-step analysis (see e.g., $[47,49]$ ) was not conducted. As a consequence, other cluster analyses using more complex data, such as socio-demographical, behavioural, or market data, could lead to the formation of different customer groups. However, the results of cluster analyses as an explorative method are generally driven by the context and aim of the analysis. Furthermore, the comparison of depositor reasons before and after the global financial crisis (see Table 8) lead to similar implications, indicating that the classification of customers does not seem to be infringed upon by the simple form of cluster analysis.

All the experts and depositors stem from German-speaking countries (and social banks). The results thus might be limited to the German and Swiss social banking market. However, this potential limitation does not reduce the implications of the results, due to the explorative character of the study. A comparative analysis concerning the development of social banks and their depositors in different countries is lacking in the relevant literature. The exploration of depositor reasons, the individual relevance of reasons, and an initial, empirically derived explanation for social bank growth of deposits provides the foundation for subsequent quantitative-comparative research approaches, which aim 
to identify differences among international social banks and their customers. For the creation of this explorative foundation, the German-speaking social banking market seems to be a good choice. German social banks increased their deposits from $€ 1.474$ billion to $€ 7.273$ billion (a $493 \%$ increase) between 2007 and 2017 [10], indicating a good fit between the sample selection and the focus on social banks' growth in the aftermath of the global financial crisis.

\section{Summary and Conclusions}

The aim of the present paper was to identify (1) a comprehensive set of depositor reasons for choosing social banks, (2) the individual relevance of the reasons found, and (3) the change of depositor reasons over time, in order to shed some light on the impact of the global financial crisis on social banks' growth of deposits.

Based on data collected from surveys with five social banks, interviews with nine industry experts, and an online survey of depositors, 18 reasons for choosing social banks were identified, which can be divided into two groups: first, reasons that address social banks' "good" characteristics (so-called "towards reasons"); and second, reasons that address conventional banks' "evil" characteristics (so-called "get away reasons"), indicating that push and pull effects are of relevance for the choice of social bank. Five potentially more important reasons were identified, such as "Shared values" or "Transparency of investments". Furthermore, these five reasons seem to generally differ from the reasons for choosing conventional banks. An observation of customer groups over time indicated that the global financial crisis might extended social banks' spectrum of customer groups through depositors that were pushed to social banks because of their rejection of conventional banks.

These findings contribute to research on social banking in multiple ways. Several reasons for holding deposits with social banks that have either gone unknown or been inaccurately described were identified. While few previous studies on depositors' choice of social banks have mostly concentrated on a small spectrum of factors, such as transparency and sustainable investing in general [10,22,29], the present findings provide a wider and more precise spectrum of potential reasons for choosing social banks. Furthermore, an initial qualitative evaluation of the individual relevance of social depositor reasons is provided. Earlier studies have already addressed the relevance of the global financial crisis for social banks' growth [6-8]. However, no studies have provided an explanation for how the global financial crisis has affected the choice of social banks. The present results indicate a potential extension of social bank customer groups, creating a first behavioural explanation for social banks' growth in deposits that paves the way for multiple avenues for further explanatory research on the impact of the global financial crisis on social banks' growth. In particular, to quantify the impact of the financial crisis on social banks' growth in deposits, as well as their potential for further growth, subsequent research attempts are supposed (1) to further assess the relative relevance of depositor reasons, (2) to quantify the proportions of customer groups, and (3) to investigate the complex structure of behavioural factors for "get away customers" choosing social banks. Based on these findings, it will be possible to assess whether social banks' growth of deposits is just a short-term sugar hill or a sustainable regime shift in the commercial banking industry. The findings also support social banks' marketing by the identification of relevant and contemporary factual information for diverse customer groups. Furthermore, three interdependent social banking features were identified that seem to be of relevance for the transformation from a conventional into a social bank.

The findings also provide practical implications for social banks and conventional banks that aim to adapt principles of social banks. The exploration of the reasons, their individual relevance, and change over time supports social banks' marketing by the identification of relevant and contemporary factual information for diverse customer groups. Furthermore, the present results enabled the identification of three interdependent social banking features that might be of relevance for conventional banks. These insights on the impact of the global financial crisis on depositors' choice of social banks enable a cautious assessment of this very topical issue. The economic crisis that will result from the current COVID-19 pandemic is not expected to have a comparable impact on the growth of social bank deposits. 
Finally, based on the identification of depositor reasons for choosing social banks and their differences to their reasons for choosing conventional banks, it is thought that the choice of social banks might be based on wholly unique reasons. The global financial crisis seems to have affected social bank growth in recent decades through an extension of customer target groups.

Funding: The APC were funded by Deutsche Forschungsgemeinschaft and University of Rostock within the funding programme Open Access Publishing.

Acknowledgments: I gratefully thank all experts, depositors, and social banks participating in the study and the Institute for Social Banking e.V. for their help and advice.

Conflicts of Interest: The author declares no conflict of interest.

\section{References}

1. Heinemann, K.; Zwergel, B.; Gold, S.; Seuring, S.; Klein, C. Exploring the Supply-Demand-Discrepancy of Sustainable Financial Products in Germany from a Financial Advisor's Point of View. Sustainability 2018, 10, 944. [CrossRef]

2. Benedikter, R. Social Banking and Social Finance: Answers to the Economic Crisis; Springer: New York, NY, USA, 2011.

3. ZEB. Social Banking Study 2012: Management Summary. 2012. Available online: https://www.zeb.eu/ lightbox_popup/nojs/1915/popup (accessed on 10 June 2018).

4. Remer, S. The social banking landscape in Europe. Glob. Soc. Policy 2014, 14, 267-269. [CrossRef]

5. Höhnke, N.; Homölle, S. The growth of social banks-A new measurement approach. In Measuring and Controlling Sustainability: Spanning Theory and Practice, 1st ed.; Lindgreen, A., Hirsch, B., Vallaster, C., Yousofzai, S., Eds.; Routledge: London, UK; New York, NY, USA, 2018; pp. 206-221.

6. Köhler, M. Sonderfrage: Social Banking. ZEW Finanzmarktreport Juli 2010, 18, 3.

7. Cornée, S.; Szafarz, A. Vive la difference: Social banks and reciprocity in the credit market. J. Bus. Ethics 2014, 125, 361-380. [CrossRef]

8. Paulet, E.; Parnaudeau, M.; Relano, F. Banking with ethics: Strategic moves and structural changes of the banking industry in the aftermath of the subprime mortgage crisis. J. Bus. Ethics 2015, 131, 199-207. [CrossRef]

9. Barigozzi, F.; Tedeschi, P. Credit markets with ethical banks and motivated borrowers. Rev. Financ. 2015, 19, 1281-1313. [CrossRef]

10. Höhnke, N.; Homölle, S. Impact Investments, Evil Investments, and Something in Between: Explaining Social Banks' Placements of Assets and Depositors' Investment Preferences. Bus. Ethics. under review.

11. Benson, K.L.; Brailsford, T.J.; Humphrey, J.E. Do Socially Responsible Fund Managers Really Invest Differently? J. Bus. Ethics 2006, 65, 337-357. [CrossRef]

12. Humphrey, J.E.; Warren, G.J.; Boon, J. What is Different about Socially Responsible Funds? A Holdings-Based Analysis. J. Bus. Ethics 2016, 138, 263-277. [CrossRef]

13. Von Wallis, M.; Klein, C. Ethical requirement and financial interest: A literature review on socially responsible investing. Bus. Res. 2015, 8, 61-98. [CrossRef]

14. Wins, A.; Zwergel, B. Private ethical fund investors across countries and time: A survey-based review. Qual. Res. Financ. Mark. 2015, 7, 379-411. [CrossRef]

15. Wins, A.; Zwergel, B. Comparing those who do, might and will not invest in sustainable funds: A survey among German retail fund investors. Bus. Res. 2016, 9, 51-99. [CrossRef]

16. Sandberg, J.; Nilsson, J. Do ethical investors want purity or effectiveness? An exploratory study on the ethical preferences of mutual fund investors. J. Financ. Serv. Mark. 2015, 20, 34-45. [CrossRef]

17. Gutsche, G.; Zwergel, B. Investment Barriers and Labeling Schemes for Socially Responsible Investments. Schmalenbach Bus. Rev. 2020. [CrossRef]

18. Goyal, K.A.; Joshi, V. A study of social and ethical issues in banking industry. Int. J. Environ. Res. 2011, $2,49-57$.

19. Cornée, S.; Kalmi, P.; Szafarz, A. Selectivity and transparency in social banking: Evidence from Europe. J. Econ. Issues 2016, 50, 494-502. [CrossRef]

20. Chew, B.C.; Tan, L.H.; Hamid, S.R. Ethical banking in practice: A closer look at the Co-operative Bank UK PLC. Qual. Res. Financ. Mark. 2016, 8, 70-91. [CrossRef] 
21. Lopez, B.; Torres, A.; Ruozzi, A.; Vicente, J.A. Main Factors for Understanding High Impacts on CSR Dimensions in the Finance Industry. Sustainability 2020, 12, 2395. [CrossRef]

22. Krause, K.; Battenfeld, D. Coming out of the niche? Social banking in Germany: An empirical analysis of consumer characteristics and market size. J. Bus. Ethics 2019, 155, 889-911. [CrossRef]

23. San-Jose, L.; Retolaza, J.; Gutierrez-Goiria, J. Are ethical banks different? A comparative analysis using the radical affinity index. J. Bus. Ethics 2011, 100, 151-173. [CrossRef]

24. Pulejo, L.; Marisca, C.; Rappazzo, N. Social reporting in European ethical banks: A comparative study. Int. J. Manag. Stud. Res. 2015, 3, 196-202.

25. Aßländer, M.; Schenkel, M. Responsible investment and exclusion criteria: A case study from a Catholic private bank. In Responsible Investment in Times of Turmoil, 1st ed.; Vandekerckhove, W., Leys, J., Alm, K., Scholtens, B., Signori, S., Schäfer, H., Eds.; Springer: Dordrecht, The Netherlands; Heidelberg, Germany; London, UK; New York, NY, USA, 2012; pp. 135-150.

26. Cowton, C.J. Integrity, responsibility and affinity: Three aspects of ethics in banking. Bus. Ethics Eur. Rev. 2002, 11, 393-400. [CrossRef]

27. Cowton, C.J.; Thompson, P. Financing the social economy: A case study of Triodos Bank. Int. J. Nonprofit Volunt. Sect. Mark. 2001, 6, 145-155. [CrossRef]

28. Akerlof, G.; Kranton, R. Economics and identity. Q. J. Econ. 2000, 115, 715-753. [CrossRef]

29. Bayer, S.; Gimpel, H.; Sarikaya, S. Bank customers' decision-making process in choosing between ethical and conventional banking: A survey-based examination. J. Bus. Econ. 2019, 89, 655-697. [CrossRef]

30. Baumeister, R.; Bratslavsky, E.; Finkenauer, C.; Vohs, K. Bad is stronger than good. Rev. Gen. Psychol. 2001, 5, 323-370. [CrossRef]

31. Rozin, P.; Royzman, E. Negativity bias, negativity dominance, and contagion. Personal. Soc. Psychol. Rev. 2001, 5, 296-320. [CrossRef]

32. Lewis, A.; Juravle, C. Morals, Markets and Sustainable Investments: A Qualitative Study of 'Champions'. J. Bus. Ethics 2010, 93, 483-494. [CrossRef]

33. Zimmermann, S. Same but Different: How and Why Banks Approach Sustainability. Sustainability 2019, 11, 2267. [CrossRef]

34. Global Alliance for Banking on Values (GABV): Member Banks. Available online: http://www.gabv.org/thecommunity/members/banks (accessed on 8 April 2019).

35. Fédération Européenne des banques Ethiques et Alternatives (FEBEA): Our Members. Available online: https://www.febea.org/map/node (accessed on 8 April 2019).

36. Institute for Social Banking (ISB): Members. Available online: https://www.social-banking.org/the-institute/ \#members (accessed on 8 April 2019).

37. Morris, R. Computerized content analysis in management research: A demonstration of advantages \& limitations. J. Manag. Inf. Syst. 1994, 20, 903-931.

38. Haniffa, R.; Hudaib, M. Exploring the Ethical Identity of Islamic Banks via Communication in Annual Reports. J. Bus. Ethics 2007, 76, 97-116. [CrossRef]

39. Bravo, R.; Matute, J.; Pina, J. Corporate Social Responsibility as a Vehicle to Reveal the Corporate Identity: A Study Focused on the Websites of Spanish Financial Entities. J. Bus. Ethics 2012, 107, 129-146. [CrossRef]

40. Pérez, A.; Rodríguez del Bosque, I. The Role of CSR in the Corporate Identity of Banking Service Providers. J. Bus. Ethics 2012, 108, 145-166. [CrossRef]

41. Majoch, A.; Hoepner, A.; Hebb, T. Sources of stakeholder salience in the responsible investment movement: Why do investors sign the principles for responsible investment? J. Bus. Ethics 2017, 140, 723-741. [CrossRef]

42. Mayring, P. Qualitative Content Analysis: Theoretical Foundation, Basic Procedures and Software Solution. 2014. Available online: https://nbn-resolving.de/urn:nbn:de:0168-ssoar-395173 (accessed on 18 March 2020).

43. Pennebaker, J.W.; Lay, T.C. Language use and personality during crises: Analyses of mayor rudolph giuliani's press conferences. J. Res. Personal. 2002, 36, 271-282. [CrossRef]

44. Landis, J.; Koch, G. The measurement of observer agreement for categorical data. Biometrics 1977, 33, 159-174. [CrossRef] [PubMed]

45. Harwood, T.; Garry, T. An overview of content analysis. Mark. Rev. 2003, 3, 479-498. [CrossRef]

46. Gray, R.H.; Kouchy, R.; Leavers, S. Constructing a research database of social and environmental reporting by UK companies: A methodological note. Accounting, Audit. Account. J. 1995, 8, 44-77. 
47. Füller, J.; Matzler, K. Customer delight and market segmentation: An application of the three-factor theory of customer satisfaction on life style groups. Tour. Manag. 2008, 29, 116-126. [CrossRef]

48. Mugge, R.; Jockin, B.; Bocken, N. How to sell refurbished smartphones? An investigation of different customer groups and appropriate incentives. J. Clean. Prod. 2017, 147, 284-296. [CrossRef]

49. Li, D.; Dai, W.; Tseng, W. A two-stage clustering method to analyze customer characteristics to build discriminative customer management: A case of textile manufacturing business. Expert Syst. Appl. 2011, 38, 7186-7191. [CrossRef]

50. Tesfom, G.; Birch, N. Do switching barriers in the retail banking industry influence bank customers in different age groups differently? J. Serv. Mark. 2011, 25, 371-380. [CrossRef]

51. Ruiz, B.; Esteban, A.; Gutiérrez, S. Determinants of reputation of leading Spanish financial institutions among their customers in a context of economic crisis. Bus. Res. Q. 2014, 17, 259-278. [CrossRef]

52. Forcadell, F.J.; Aracil, A. European Banks' Reputation for Corporate Social Responsibility. Corp. Soc. Responsib. Environ. Manag. 2017, 24, 1-14. [CrossRef]

53. Nájera-Sánchez, J.J. A Systematic Review of Sustainable Banking through a Co-Word Analysis. Sustainability 2019, 12, 278. [CrossRef]

Publisher's Note: MDPI stays neutral with regard to jurisdictional claims in published maps and institutional affiliations.

(C) 2020 by the author. Licensee MDPI, Basel, Switzerland. This article is an open access article distributed under the terms and conditions of the Creative Commons Attribution (CC BY) license (http://creativecommons.org/licenses/by/4.0/). 